\title{
$[6]$
}

\section{Problems of Misreading:}

\section{The "Prologue" to}

\section{The Legend of Good Women}

$\mathrm{Al}$ ne is nat gospel that is to yow pleyned;

The god of Love hereth many a tale yfeyned.

Chaucer, The Legend of Good Women

About the time Chaucer was at work on The Canterbury Tales, it is likely that he paused, perhaps in 1386 , and wrote the "Prologue" to The Legend of Good Women. This return to the form of the dream vision, which he had abandoned before composing Troilus and Criseyde, has often puzzled readers-understandably-since it apparently interrupts the development of Chaucer's craft that can be traced from the early poems through Troilus and the Tales. ${ }^{1}$ More unusual still, in 1394 or 1395 , when he was well under way with the Tales, Chaucer probably returned again to the first version of the "Prologue" (F) and revised it. The revision (G) differs from the earlier $\mathrm{F}$ text in its elimination of certain personal and biographical matters, such as the directive toward the end of the poem:

"And whan this book ys maad, yive it the quene,

On my byhalf, at Eltham or at Sheene."

$$
\text { (PLGW, F 496-497) }
$$

'The issues involved in the return to the dream vision, including the dating of the poem, are conveniently summarized by John H. Fisher, "The Legend of Good Women," in Companion to Chaucer Studies, ed. Beryl Rowland, rev. ed. (New York: Oxf ord University Press, 1979), pp. $464-476$. 
Chaucer also excised from $\mathrm{F}$ some elements that seem only tertiary to storial sequence, such as the passage at the opening of the poem from Boccaccio's Filostrato describing the lady as a celestial light and a musician who is exhorted to play upon the poet's heartstrings and inspire his song ( $P L G W, \mathrm{~F} 84 \mathrm{ff}$.). The deletion of such figures from the $F$ text obviously serves the formalities of narrative-concise action (unimpeded beginning, middle, and end), adequate characterization, and crisp sentence. Since these are the virtues of narrative in the Tales, it is understandable that Chaucer might wish to perfect them in the later $G$ text; but it is not quite so easy to explain why he would leave the Tales in the first place and return to a form set aside many years before.

Notwithstanding the improvements of the G version, the "Prologue" has by no means satisfied its critics. That they have mostly, but not exclusively, preferred the more refined $G$ text suggests that interpretation has taken its lead from narrative and that all elements of the poem are subordinated to it - or else they would be eliminated. ${ }^{2}$ This assumption deserves scrutiny, insofar as one of the causes of the dissatisfaction some have had with the poem lies in the disjunction between narrative sequence and the apparent interest of the text in matters with little or no immediate bearing on it. Thus the "Prologue," not unlike The House of Fame before it, poses for me an interesting example of a work in which a principle of authority - either the narrator's voice or the voice of the narrative-does not prevail completely over the meaning of the text, and the question of indeterminacy is again at stake in Chaucer's game of "soth," "fals," and the reader's response. In the following pages, I will be attending to what Chaucer is playing with on the fringes of the narrative about "his" arraignment before the God of love. ${ }^{3}$

One of the first of these oblique passages occurs at the opening of the poem, the sweeping discussion about validating knowledge concerning the afterlife and believing in the claims of old books.

${ }^{2}$ Fisher reviews the positions taken in preference for $\mathrm{F}$ and $\mathrm{G}$; he prefers the earlier F version because it includes biographical details; Companion, p. 469.

${ }^{3}$ It might be pointed out that my argument for the qualification of narrative in the "Prologue" compares with J. A. Burrow's view that Chaucer deviates from the "Ricardian" preference for narrative by submitting storytelling to the game of fictionalizing in The Canterbury Tales; see Ricardian Poetry: Chaucer, Gower, Langland and 
The passage $\left(P L G W, G_{1}-28\right)$ need not be quoted as an example of a typically medieval respect for auctoritates: without them the past would be forgotten; a book is the "keye" that will release the hasp of the closed text of "remembrance" - the Book of culture's memory, history. ${ }^{4}$ But the exact relevance of this opening to the ensuing story is not the subject of much critical attention in early readings of the "Prologue." They are much more interested in the subsequent passage about the worship of the daisy, and consequently they prefer the elaborate extensions of this image in the $\mathrm{F}$ version. ${ }^{5}$ An obvious explanation of this interest is the metaphorical extension of the image of the daisy to the imagery of Queen Alceste and the Garden of Love. Since this kind of extension is to be found in contemporary French sources-such as the marguerite poems of Deschamps and Machaut - it has been maintained that Chaucer's intention is predominantly making a model of the French allegory and that the $\mathrm{F}$ text, in which the daisy metaphor is more elaborate, is therefore the preferred version.

But the expectation for congruence between the story of the court of love and a presumed story about Chaucer at the court of Richard II proved to have a stronger hand on the meaning of the poem. The argument that the image of Alceste the daisy is not an allegorical image linked back to French marguerite poetry, but rather refers to Richard's queen, Anne of Bohemia, also prefers the $\mathrm{F}$ text, though for entirely new reasons (historical allegory), and rests its case on the exclusion of biographical details from the poem after Anne's death in $1394 .{ }^{6}$ The appeal of this approach

the "Gawain" Poet (New Haven: Yale University Press, 1971), p. 88. For the conflict of "secrecy" and narrative, see my previous chapter and the two works by Frank Kermode, The Genesis of Secrecy: On The Interpretation of Narrative (Cambridge: Harvard University Press, 1979), and "Secrets and Narrative Sequence," CI 7 (1980): $83-101$.

'The text a s a "keye" may also suggest that reading will open the gate into the garden in which the dreamer finds himself in the body of the poem. But, as Robert $\mathrm{O}$. Payne has indicated, books in this passage are linked to "tradition"; The Key of Remembrance: A Study of Chaucer's Poetics (New Haven: Yale University Press, 1963), p. 94. Thus I suggest that "remembrance" relies on the metaphor of the book of memory or the past that will be unlocked by the key of reading a book-in this case Chaucer's poem.

${ }^{5}$ G. L. Kittredge, "Chaucer and Some of His Friends," MP 1 (1903):1-18; J. L. Lowes, "The Prologue to the Legend of Good Women as Related to the French Marguerite Poems and to the Filostrato," PMLA 19 (1904):593-683, and the same author's "The Prologue to the Legend of Good Women Considered in Its Chronological Relations," PMLA 20 (1905):749-864.

${ }^{6}$ J. S. P. Tatlock, The Development and Chronology of Chaucer's Works (1907; reprint, Gloucester, Mass.: P. Smith, 1963); Hugo Lange, "Zur Datierung des GG-Prologs Chaucers Legende von guten Frauen: Eine heraldische Studie," Anglia 39 (1915): 
and its long scholarly standing may be attributed to the authorization of an assumed narrative of real historical events: Chaucer may have offended women of importance in fourteenth-century society - perhaps even the queen of the realm - by composing allegedly "antifeminist" works, Troilus and Criseyde and the translation of the Romance of the Rose (both named in the poem, G 255, 265). Public reaction probably arose to protest this of fense of good taste in the charges delivered by the God of Love ( $\mathrm{G} 24 \mathrm{off}$.); defenses are mounted by both a patron, Alceste $(\mathrm{G} 318 \mathrm{ff}$.), and the poet $(\mathrm{G}$ $446 \mathrm{ff}$.), but they cannot prevail over conventional propriety in matters of good literature, and as a result the poet must do "penaunce" by spending most of his time writing poems favorable to women, "a gloryous legende / Of goode women" (G 473-474)..$^{7}$ The demand for narrative sense in the poem, ordered by the God of Love, has been answered more than adequately by modern readers of the "Prologue": their reading is "medieval" both for its claim to represent English court life in the fourteenth century and for its appeal to the custom that history should make narrative sense.

A major reinterpretation of this reading of the poem expands the reference to the defense of "bad" or "antifeminist" literature to include the much broader idea that Chaucer is writing a general defense of his poetry; although a palinode for Troilus, the "Prologue" to the The Legend of Good Women is also Chaucer's first fullfledged effort to put forth an ars poetica of all his work. ${ }^{8}$ Setting aside the priority of historical reference, though maintaining the propriety of narrative sequence, this reading is one of the most concerted attempts to justify the obscure relationship at the opening between respect for old books and the desire for the flower. ${ }^{9}$ It suggests that the two present a basic contrast, insofar as books stand in opposition to the experience of nature when the "source"

347-355; Viktor Langhans, "Der Prolog zu Chaucers Legende von guten Frauen," Anglia 41 (1917):162-181.

'The control of narrative on interpretation is obvious in the intricate variations that have been proposed for the assumed "story" that occasioned the poem. For instance, Margaret Galway would substitute King Richard's mother, Joan of Kent, and her husband, the Black Prince, for Alceste and the God of Love; see "Chaucer's Sovereign Lady: A Study of the Prologue to the Legend and Related Poems," MLR 33 (1938):145-199. Her view has not gone unchallenged: see Bernard F. Huppé, "Chaucer: A Criticism and a Reply," MLR 43 (1948):393-399; Paul G. Ruggiers, "Tyrants of Lombardy in Dante and Chaucer," $P Q 29$ (1950):445-448.

${ }^{8}$ In The Key of Remembrance, Payne examines the possibility of this project in the "Prologue." See also D. C. Baker, "Dreamer and Critic: The Poet in the Legend of Good Women," UCSLL 9 (1963):4-18.

${ }^{9}$ Payne, Key, pp. $94 \mathrm{ff}$. 
for the inspiration of poetry is at issue. And that issue is precisely the theme, according to this reading, of Chaucer's "Prologue"; to document it we need only refer to the story, which is determined to probe for a satisfying resolution. But the movement back and forth between books and experience suggests that traditional and pragmatic approaches to knowledge appear to be irreconcilable opposites. Moreover, the narrator's mask of ignorance functions as a defensive strategy for not facing the problem. Nonetheless, it is acknowledged, in this view of the poem, that the story gradually moves toward harmonious resolution, for instance, in the Balade (PLGW, G 203-223), which celebrates Alceste as "the figurative transformation of the daisy." ideal with the traditional past"; in her the singing maidens prefigure "a possible identity of experience, vision, and books." "But the dreamer remains ignorant of this coalescence, which, it seems, is possible only in the ideal world of dreams.

The reconciliation imminent in the Balade does not characterize the "Prologue" as a whole, according to this argument, and that problem is set before us in the charges of the God of Love. He blames "Chaucer" not for what he has done but for what he has written, and this attack summarizes two crucial points in poetics: one, that Chaucer has not chosen the proper sources for composing poetry, and two, that the intention he had "in mynde" (PLGW, G 270 ) has not been realized in writing. ${ }^{12}$ To these provocative problems, in the view summarized here, Chaucer has no answer. Alceste comes to the poet's defense, but she "begs the question altogether." The story seeks an answer to a comprehensive matter - "the nature and function of art and the justification of the artist"; but when the God of Love affirms "that the poet must know truth, must himself know how to select the right traditional means, must manage to do actually what he intended ideally - then everything stalls."13 Instead of an answer, Chaucer retreats into "ironic evasions," and the story of the "Prologue," which had set out to "escape from the circularity of the old, compulsive, book-experiencedream pattern ... takes Chaucer exactly nowhere." ${ }_{14}$

While the premise of this study of the "Prologue," which is based on what the story actually says, is entirely customary in the inter-

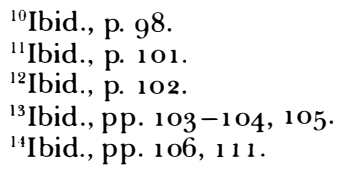


pretation of medieval literature, the argument does not entertain the possibility that the narrative raises a problem the text is not necessarily interested in solving. Rather, the problem is treated as if the poem minimizes or completely excludes any strategies for play. Humor is of course observed, but it is assigned, and this point is significant, exclusively to the category of character in the poem - such as the portrait of the dreamer-poet. His characterization at the opening of the "Prologue" is one of the most vivid examples of the Chaucerian persona as the pedantic, love-struck dreamer, not quite capable of finding his way to the end of the next sentence. From the assumption about the continuity of this persona in the early poems of Chaucer, one may imagine that the $G$ text itself is the final "chapter" in Chaucer's "myth" about slowly making his way into the Garden of Love and Art. ${ }^{15}$ But just as the hyperbole about ignorance creates a certain humor in characterization, it also considerably qualifies the perception of the problem that the narrative begins with. We may say, as some have, that Chaucer opens the poem with a serious question posed through the voice of an unserious speaker, the dreamer; but the "voice" of the text, which is separate from that speaker, is unserious too. ${ }^{16}$

For instance, the doubt about validating the nature of invisibilia is followed by the observation that since such things cannot be proved, one ought to believe in authorities, such as "Bernard":

\section{this wot I wel also,}

That there ne is non that dwelleth in this contre,

That eyther hath in helle or hevene ybe,

Ne may of it non other weyes witen,

But as he hath herd seyd or founde it writen;

For by assay there may no man it preve.

But Goddes forbode, but men shulde leve

Wel more thyng than men han seyn with ye!

Men shal nat wenen every thyng a lye,

For that he say it nat of yore ago.

God wot, a thyng is nevere the lesse so,

Thow every wyght ne may it nat yse.

Bernard the monk ne say nat al, parde!

$\left(P L G W, \mathrm{G}_{4-16)}\right.$

\footnotetext{
${ }^{15}$ See Robert O. Payne, "Making His Own Myth," Chaucer Review 9 (1975): 197-211.

${ }^{16} \mathrm{John}$ M. Fyler has pointed out some of the unserious qualities of the "Prologue" in Chaucer and Ovid (New Haven: Yale University Press, 1979), pp. 197-198, $118 \mathrm{ff}$. But by and large, most readings of the "Prologue" assume the questions about poetry and reception are raised in earnest.
} 
The identity of the "Bernard" intended here is uncertain, and perhaps the obscurity is to the point, for the passage appears to question the claim to authority that it is affirming: on the one hand, the narrator seems comforted that even Bernard (the mystic of Clairvaux?) did not see all invisibilia in his celestial vision, and therefore one should not trifle about what less divine persons cannot see; but on the other hand, the passage also says that Bernard (whoever he was) did not see everything, and therefore one need not defer to him, since everyone is in the same position regarding what "in helle or hevene ybe." 17

From such a qualified position, the imperative of the subsequent lines cannot be moved without a certain strain of logic:

Thanne mote we to bokes that we fynde,

Thourgh whiche that olde thynges ben in mynde.

$\left(P L G W, \mathrm{G}_{17}-18\right)$

Although the "olde thynges" constitute "doctryne" (PLGW, G 19) about the transcendental order, the next class of things to which we should "yeven credence" and "trowen" $(P L G W, \mathrm{G} 20,21)$ with all of our skills is:

olde aproved storyes

Of holynesse, of regnes, of victoryes,

Of love, of hate, of othere sondry thynges,

Of which I may nat make rehersynges.

$(P L G W, \mathrm{G} 21-24)$

This is the stuff fictions are made of, and yet there is no acknowledgment whatever from the speaker that any difference exists between belief in the "invisible things of God" and the "invisible" illusions that fictions make. To him they are of the same order of reality. There is no "assay by preve," no experience for proof, that will validate what is in heaven and hell or how it differs from what is recorded in fictions about them, such as Dante's Paradiso and Inferno. For at least one reader of these lines, Chaucer's intent in requesting "credence" is not unlike Coleridge's remark on the "willing suspension of disbelief" that constitutes "poetic faith." ${ }^{18}$ But

${ }^{17}$ Gabriel D. Josipovici has also observed the play in this passage; see The World and the Book (Stanford: Stanford University Press, 1971), pp. 56-57. But the customary response is that the passage insists seriously on believing in old books; for instance: Payne, Key, 94-97; Robert Worth Frank, Jr., Chaucer and "The Legend of Good Women" (Cambridge: Harvard University Press, 1972), pp. 19-21.

${ }^{18}$ Frank, Chaucer and "The Legend," p. 19. 
Chaucer's passage has begun with an obviously different kind of "faith" - not in the power of human illusions but in the events of history and the afterlife.

The comparison of the divine to the fictive ordo will stretch only so far before we hear the voice of the text playing with the insistence of the speaker, complaining against the way he and his narrative are inviting us to read. They are palpable, definite, and formal, while the voice of the text emanates from far less determinate properties of writing, such as the uncertain identity of "Bernard" or the shaded meaning of "trowen" when it involves "storyes." The passage, to sum up, does not simply raise a point about the "tone of voice" in which we are to take problems about the source of poetry and belief in it. Rather, the narrative carries these matters forward at the same time as the nonsequential elements of the text get in the way of their resolution. The narrative, to put the matter another way, does not act as the signifier of what the text as a whole means. The causality of storial sequence is interrupted by the play of distracting elements. An important group of such elements is the extension of the image of the daisy in the many agrarian images of the poem. They are not comfortably subordinated to storial sequence, and predictably they have gone, by and large, unremarked in readings of the poem. Before turning to them, it will be useful to note briefly that the daisy itself has seemed much more manageable to readers, because it is assimilated quite deliberately into the narrative of events.

3

One of the first explanations of the differences between the two versions of the "Prologue" maintains that the redaction in the $G$ text of the extended language of devotion to praise a mere flower reflects a new religious conservatism in the poet. In his revisions, it has been argued, Chaucer attempts to eliminate any possibility of blaspheming religious institutions by the free mingling of sacred language and secular pleasures. ${ }^{19}$ This explanation of editorializing is made with a firm grip on narrative sense, since it forthrightly distrusts the shaded meaning and secret sense of words. Curiously

${ }^{19}$ Dudley D. Griffith, "An Interpretation of Chaucer's Legend of Good Women," in Manly Anniversary Studies (Chicago: University of Chicago Press, 1923), pp. 32-41. See also Raymond Preston, Chaucer (1952; reprint, Westport, Conn.: Greenwood Press, 1969), and Marvin J. LaHood, "Chaucer's The Legend of Lucrece," PQ 43 $(1964): 274-276$. 
enough, this grip is no less firm in a reading that claims to be less moralistic and more sensitive to the play of exaggeration and parody in the text. This view turns the object of hyperbolic worship away from the religious references in the language and back toward the speaker who is doing the exaggerating. A greater degree of play is granted in this explanation of parody, which, by the way, is recognizably more medieval in its claim that parody most commonly falls back on the parodist. In this case the exaggerated praise of the flower is yet another subtle debunking of the naive dreamer: "the hyperbolic language and postures are typical for devotion to ladies, but comic for devotion to daisies." ${ }^{20}$ The dreamer, however, knows not the difference, and in him we recognize a precursor of such figures as Absolon in The Miller's Tale. But while this reading attends to the play in the dreamer's speech, it nonetheless limits hyperbole to the function of character in the "Prologue" and follows the lead of narrative, claiming that the dreamer's desire to please the daisy, that is, the queen, will be fulfilled in finding the right sources for poetic praise.

This reading is clearly satisfied by the demands for narrative sense, which assimilates the daisy unmistakably into the imagery of the queen. But the story does not apologize or explain why the narrator, once the image of the flower is on his mind, cannot prevent it from playing with what he is trying to say. Words get in the way of his intention and trick him into saying what he does not mean. Before recording the dream, the narrator confesses that he lacks the tongue to praise the flower properly, and the image triggers a string of agrarian images.

For wel I wot that folk han here-beforn

Of makyng ropen, and lad awey the corn;

And I come after, glenynge here and there, And am ful glad if I may fynde an ere Of any goodly word that they han left. And if it happe me rehersen eft Than they han in here freshe songes said, I hope that they wole nat ben evele apayd, Sith it is seyd in fortheryng and honour Of hem that eyther serven lef or flour. For trusteth wel, I ne have nat undertake As of the lef agayn the flour to make, $\mathrm{Ne}$ of the flour to make ageyn the lef,

${ }^{20}$ Frank, Chaucer and "The Legend," p. 22. 
No more than of the corn agen the shef;

For, as to me, is lefer non, ne lother.

I am witholde yit with never nother;

I not who serveth lef, ne who the flour.

That nys nothyng the entent of my labour.

For this werk is al of another tonne,

Of olde story, er swich strif was begonne.

(PLGW, G 61-80)

Although a redaction of the extended floral imagery in the $\mathrm{F}$ text, this passage is still more elaborate than the story demands. A certain quality of the style is the result of the French influence on the poem, and other aspects of it serve the characterization of the narrator's pedantry; but the rest of it has less definable purposes within the story proper. The narrator imagines himself a harvester walking through a vast "field of writing" ("makyng") after it has been "reaped" and seeking to find even a single "ere" of "corn" (or "wheat") as a suitable literary mode for praise. Confessing his inability, the narrator moves on to another metaphor, the game of the "leaf and the flower," in order to say that his own efforts have little to do with the poetry composed in the springtime game of praising the leaf or the flower as a symbol of love. His poetry is not such a game of preferences, and that disavowal clearly links the figure to the narrative as a prefiguration of his subsequent defense against the God of Love's charges that he has in fact taken sidesthe wrong ones - in choosing for his poetry the stories of Amant and Criseyde.

But the text of the narrator's speech is more suggestive than he knows. While he is playing with language at the opening in the metaphor of the "field of writing" in which he finds not an "ere," it becomes evident that language is simultaneously playing with him. Initially the game is to his advantage, when the voice of the text puts words in his mouth by requesting-modestly through the pun - the attention of any "ear" in the audience who will be kind enough to listen to the "goodly word" of the poem. However, the figure of the game of writing poetry (the "leaf and the flower") does not work entirely in his favor, since the play of puns and ambiguities contradicts the disavowal he asserts. First of all, concealed in his image of the harvested "field" of literary history is the buried metaphor of nature and history as a "page" or Book, like the "Estoryal Myrour" of Vincent of Beauvais, mentioned by the God of Love (PLGW, G 307). The figure is surely a venerated one for 
establishing a claim to writing competence, but that is not exactly what our dreaming poet is trying to say. Furthermore, when the metaphor of writing is set in context with the elaborate game of the leaf and the flower, the play of references is no longer within the narrator's control. The game continues as the verb "make" (PLGW, G 72) echoes the earlier reference to "makyng" as "writing" (PLGW, G 62); thus if the speaker will not undertake "the lef agayn the flour to make" (PLGW, G 71-72), he cannot help but suggest that he will not make the "leaf" or "page" of his book of poetry into an imitation of the "flower" of literary convention-precisely the opposite meaning of his desire to find even one ear of corn in that convention. ${ }^{21}$ Carrying on his game at the level of syntax, the narrator completes the chiastic structure of his sentence- "ne of the flour to make ageyn the lef" (PLGW, G 73)-but he cannot prevent the echo in it that he will not turn the flowers in nature's Book into the "leaf" of his writing, yet another contradiction of his expressed wish to venerate his special flower in the leaves of his book.

He may, as he says, have no interest in the garden game of writing poetry, but his disclaimer manifests some of the most subtle games that language can play when we hear echoes of the learned activity of reading that is a process of turning the "leaf" of the sensus literalis into the "flour," the farina, of intelligible meaning. ${ }^{22}$ Striving to punctuate his separation from the garden game of writing, he compares it to a magician's trick of transforming the "corn" back into the "shef" (PLGW, G 74), but the line unmistakably extends previous images of exegetical writing, which is God's "trick" of putting the "corn" of the sensus spiritualis into the "shef" of the sensus literalis in the Books of Scripture, nature, and history. Only deafness to such echoes (which will also distinguish such other characters as Chaucer's Wife of Bath) could justify the indiscriminate echo of the next line that the "literature of the lef"- - the literal meaning of things - is no different to him from the "writing of the flour" - the invisible things of God, "for, as to me, is lefer non, ne lother" (PLGW, G 75). ${ }^{23}$ But as he disavows the game of the "lef," it makes a final embarrassing reappearance in "lefer," snar-

\footnotetext{
${ }^{21}$ Chaucer uses "leaf" to refer to "page," for example, in the "Prologue" to The Miller's Tale: "Turne over the leef and chese another tale" (3177).

${ }^{22} \mathrm{This}$ commonplace is recorded, for instance, by Alanus de Insulis, Distinctiones $(P L 210,785-786)$, s.v. "farina."

${ }^{23}$ On the Wife's spiritual deafness, see D. W. Robertson, Jr., A Preface to Chaucer: Studies in Medieval Perspectives (Princeton: Princeton University Press, 1962), pp. $317-331$.
} 
ing him in the larger game of language. Before closing his remarks, the narrator leaves us with one more image, this time apparently moving away from the agrarian vocabulary for writing. He says that the "entent of my labour," "this werk" (PLGW, G 78 , 79) - which is the "Prologue" to The Legend of Good Women-is of another kind completely, and so he chooses another metaphor, "tonne" - "kind" or "cask" (for containing water or wine). The echoes from the history of writing as a "cask of wine," or water in a cask changed into wine, are at most muted and do not carry on the play of multiple senses. ${ }^{24}$ But the rules of another game have come into play, the rules about mixing metaphors in poetry, and they control the voice of the text, despite the narrator's ignorance of them in his continuing search for the right terms for praising his daisy.

As the narrator and his story persuade us to read for the answer to the question of poetic genesis - the proper source for poetry - the game of language protests against that invitation. The effect of this conflict is that the story about the defense of poetry as a search for the right source runs up against the plurivalent significance in writing, thereby qualifying the search as the primary "meaning" of the text. Instead of the discovery of a source in the form of a book or authority, the "Prologue" to The Legend of Good Women, like The House of Fame, reveals that the narrator's problem is in the writing itself, in the proper communication and reception of what he composes. More broadly, the development of his story in the text of the "Prologue" constitutes an exemplum of the larger issue that narrative, which seeks to determine meaning, is itself determined by its reception. ${ }^{25}$ The introduction of the "Prologue" closes with a summary of the problem of response. To the mind of the narrator, it is a question of unqualified belief in the sincerity of authority.

\footnotetext{
${ }^{24}$ In the Reeve's "Prologue," "tonne" signifies the "cask" of the Reeve's life that is flowing like wine from an open tap $(3891-3895)$. "Wine" (vinum) is a commonplace for "spirit" (anima) and "word" (verbum), notably the words of the Gospel; see Alanus, Distinctiones (PL 210, 1004-1005, s.v. "vinum"; and Allegoriae in sacram scripturam (PL 112, 1078-1079), s.v. "vinum."

${ }^{25} \mathrm{Cf}$. Burrow: "So the meaning of an 'ensample' depends not on its content but on the variable 'entente' of the people who use it. Alceste dismisses this very Chaucerian argument rather impatiently . . . she dictates the content of the Legends, but leaves the poet free in the critical matter of 'entente.' Chaucer quite fairly makes the most of this freedom, and produces a set of examples whose meaning, like that of The Nun's Priest's Tale, is extremely elusive and equivocal. Even the opening paragraph of his poem, with its unexceptionable sentiments about believing old books ... turns out ... to be a booby-trap"; Ricardian Poetry, pp. 91-92.
} 
But wherfore that I spak, to yeve credence

To bokes olde and don hem reverence,

Is for men shulde authoritees believe.

$$
(P L G W, \text { G } 81-83)
$$

His own efforts have tried to respect that value, as he changes metaphors for the text — "field," "corn," "lef," "flour," "tonne" — in the well-meaning attempt to find the right one. In this search for the word that will not, presumably, be veiled by obscure senses, he finally chooses an image of the "unveiled" word itself: he is going to give us, he says, the "naked text" (PLGW, G 86). The "entente" is apparently to produce a text no longer bothered by ambiguous words or the dress of custom, a book whose meaning is selfdisclosed and fully present, as the events in a narrative sequence make sense and add up clearly to an explicit sentence. However, his wish will be misspent, for his first "reader," the God of Love, imposes on him precisely those demands for the plain sense of things - the "pleyn text" (PLGW, G 254)-and yet the response of that deity simply will not serve as an index of adequate reading. As a result, the narrator's dream of a "naked text," an achievement so clear that words will seem like unnecessary clothes, remains only a dream, an illusion of a presence that fades out of reach behind the veil of words. ${ }^{26}$

The "Prologue" develops at great length the disjunction between the God of Love's demands on the poet and their fulfillment. If we consider only one side of this opposition, such as the argument that the God of Love's charges pose serious questions about poetic genesis, the conflicting evidence of his bias as a reader is suppressed. But it is quite apparent that the "Prologue" is interested in the conflict itself. For instance, the God of Love's demands emanate from sources of power and authority; what he will have to say about po-

\footnotetext{
${ }^{26}$ Chaucer's use of the image of "nakedness" to suggest the limited appeal of the narrative of full disclosure may be compared with Roland Barthes's observations on reading. Barthes extends the same image elaborately and playfully to suggest that the "pleasure of the text" consists not in narrative suspense, which compares with nudity, the Oedipal pleasure ("to denude, to know, to learn the origin and the end"), but in "intermittence" (like "skin flashing between two articles of clothing"), in the "staging of an appearance-as-disappearance"; The Pleasure of the Text, trans. Richard Miller (1973; reprint, New York: Hill and Wang, 1975), p. 10.
} 
etry is proprietary, and we are prepared for it by the abundant attention to formality and custom in the dream. These patterns, which are rendered in the florid, dreamlike style typical of vision poetry, also serve another purpose - the preparation of the narrator's dream as the illusion of a revelation and the veil of an exposure that will remain out of reach. Birdsong prepares for the God of Love's entry, the garden is enchanted with foliage and sunlight, the lark announces the arrival of this "myghty god of Love," who with "wynges sprede" appears, accompanied by his "quene / Clothed in real habyt al of grene" (PLGW, G 142, 145-146). Words have the quality of elaborate clothing in the rich description of these deities; the God of Love has stepped out of the magnificently illuminated pages of such books as the Romance of the Rose; he is a painter's model. Formality continues in a variety of elements, for example, in the entourage of the "ladyes nyntene" ( $P L G W, G$ 186) who follow the King and Queen of Love, kneel in honor of them, rise, form a compass, and dance - "carole-wise" (PLGW, G 201) - while singing in high poetic style the Balade in praise of Alceste. For the narrator, words are the songs of visionary maidens.

Within the context of this paradisal setting, the appearance of the dreamer stands out starkly as an impropriety, and the God of Love so indicates it by his choice of imagery, which quickly returns us to earth:

"What dost thow her

In my presence, and that so boldely?

For it were better worthi, trewely,

A worm to comen in my syght than thow."

(PLGW, G 241-244)

The mere presence of this poet is an offense to decorum and good taste. But it immediately becomes obvious that the God of Love's literary propriety is limited to works that favor the notion of the service of love, which means, particularly, works that avoid suggestion, innuendo, shaded meanings, and the intricate internal workings of fully wrought characters. ${ }^{27}$ Thus he repudiates "Chaucer" for the stories of Criseyde and Amant; their "goodness" is not clear; their appreciation of love is concealed; their appearance is far too seductive; their narratives do not af firm the supremacy of this god, no matter how fully they expose themselves. Rather, their

\footnotetext{
${ }^{27}$ Fyler has called the God of Love a "literal-minded reader"; Chaucer and Ovid, p. 97 .
} 
exposure turns out to be an illusion of motives and causes that remain secretive, concealed behind their words. The God of Love cannot be bothered by the elements of narrative that are hidden from view, alien to sequence. All of that materia occulta somehow belongs to the category of "chaf," while stories that do not confuse him with cross-purposes and nonsequential elements are works of admirable "corn."

Was it to the, to write unstedefastnesse

"A ful gret neglygence

Of women, sith thow knowest here goodness

By pref, and ek by storyes herebyforn.

Let be the chaf, and writ wel of the corn." ${ }^{28}$

(PLGW, G 525-529)

The authority he stands for in this royal Court of Reading aligns itself with storial sense - the "pleyn text"; but the utterly inadequate expectations of his "reading" deauthorize his authenticating demands for narrative. As the narrator at the end of the introduction to the "Prologue" imagined a way out of the game of language by promising a book without secrets, "the naked text," the literary criticism of the God of Love leaves us wondering what the possible pleasures of such a text might be.

Readers have often turned to Alceste's defense of the narrator, hoping to find answers to his problems with the source and intention of poetry. But just as frequently they have been disappointed. She does not, it has been argued, answer the questions in poetics about proper sources and determinate meaning. At least one reader, however, has felt that despite the weakness of her defense she does unify the bifurcated matter with which the introduction to the "Prologue" begins, the division between books and experience. ${ }^{29}$ In this view she is the synthesis of the conflict, because she becomes a figure of the unifying power of the poetic imagination. ${ }^{30}$ As the story develops toward recognizing the identity of Alceste as the daisy, so the dreamer's spiritual development reaches fruition in the reconciliation of opposites-books and experience, tradition and individuality, art and nature. In this view, the foreshadowing of nineteenth-century concepts of the poetic

\footnotetext{
${ }^{28} \mathrm{Cf}$. lines 311-312: "But yit, I seye, what eyleth the to wryte/ The draf of storyes, and forgete the corn?"

${ }^{29}$ Robert B. Burlin, Chaucerian Fiction (Princeton: Princeton University Press, 1977), pp. $38-44$.

${ }^{30}$ For Burlin's discussion of imagination, see ibid., pp. 26-32.
} 
imagination (as formulated, for example, by Coleridge) is quite deliberate. It is offered as a new solution to the problem of experience in the "Prologue." But it refers to the "experience" of the imagination, not of the physical world.$^{31}$ While it may be important to consider the concept of the imagination in Chaucer's works, the "Prologue," I think, addresses more pragmatic matters, such as the problems of writing clearly and reading adequately. Alceste is very much interested in these issues, and it will be worthwhile to take the lead of those who see a way out of the narrator's dilemmas through her defense.

To begin with, her effectiveness consists not in what she reveals, but in what her defense does not say. She is not the fulfillment of the narrator's dream of the fully self-disclosing speaker whose words, like dress or custom, fall away to expose pure intentions. On the contrary, she, like the God of Love, is depicted in the magnificent costume of royalty amid the enchanting surroundings of the garden.

Upon the softe and sote grene gras

They setten hem ful softely adoun,

By order all in compas, enveroun,

Fyrst sat the god of Love, and thanne this queene

With the white corone, clad in grene,

And sithen al the remenant by and by,

As they were of degre, ful curteysly.

(PLGW, G 225-231)

When she speaks to the God of Love about the poet, the narrative leads us to expect a successful defense. But readers generally have agreed that she begs the question. For instead of defending the dreamer, she throws him on the mercy of the court, observing that the God of Love, because he is a deity, should be "ryghtful" and "mercyable" (PLGW, G 323); some of the remarks circulated about the poet, she claims, may be just gossip or lies:

$\mathrm{Al}$ ne is nat gospel that is to yow pleyned;

The god of Love hereth many a tale yfeyned.

For in youre court is many a losengeour.

(PLGW, G 326-328)

\footnotetext{
${ }^{31}$ In a review of Burlin's book, Lee W. Patterson has pointed out this qualification; "Writing about Writing: The Case of Chaucer," UTQ 48 (1979):263-282.
} 
Furthermore, what the poet wrote was innocent: he "nyste what he seyde" (PLGW, G 345); finally, the writer is a court poet and may have been ordered to compose the poems in question. When read in this way, according to the demands of the story, the defense thoroughly concedes the poet's guilt. However, the narrator remains enchanted by his apologist, and her identity is until the very end an elusive mystery that charms him. Her beauty apparently makes up for what she does not say. This concealment is a quality of attraction that also characterizes the text of her defense. It is effective, in other words, because it is not "the naked text" of the narrator's wish. Its motives remain cleverly concealed: through the concession of the poet's guilt, the speech establishes a most subtle defense of poetry.

She speaks to the God of Love with the aplomb of the wife who knows her husband's anger better than he does. Withholding her intentions and acknowledging his impeccable demands for propriety, she suggests that "curteysye" ought to prevail in the trial; because he is a "deite," stability should counterbalance anger. But Alceste's concealment makes itself felt in yet another way -in her veiled words. She speaks a good deal about the "lies" that the God of Love has heard, the "tale yfeyned" from "many a losengeour" and "queynte totelere accusour" (PLGW, G 329). These lies may well allude to false stories circulating about the poet in Richard's court. But what are "lies" in the world of fiction if not the stories that the poet himself has written - false, because that is what fictions are, not historical fact or truth, but "many a tale yf eyned." In the hypothetical, feigned realm of poetry, the God of Love has heard about "falsenesse," but specifically as it exists in the heart of Criseyde, and "jelous ymagynyng" as it fires the imagination of Amant in his pursuit of the rose (PLGW, G 331). Chaucer's Troilus and his translation of the Romance are blamed as the records of authors who have sought to have "som dalyaunce" (PLGW, G 332) with love. While one may think of them as envious writers seeking favor from the nobility, it is more likely that they are the misbegotten lovers who rival "Envye" as Troilus does thinking of Diomede, and imagine it as the "lavender" who will spread unkind gossip among his friends or in the house of Criseyde. These situations may seem to have claim to historical truth, like events in the Bible, but, says Alceste, "Al ne is nat gospel that is to yow pleyned" (PLGW, G 326). On the contrary, the "lies" of which the defendant is accused are his fictions-perhaps deserving comparison, as Alceste mentions, with works by "Dante" (PLGW, G 336). There- 
fore "Chaucer" has "wrongly ben acused" (PLGW, G 338); he wrote in "innocence," not because he was too stupid to realize what he had written (he "nyste what he seyde"; PLGW, G 345), but because "he" did not say it: Criseyde, Troilus, Amant, Envye, a host of others - they said it; and the text "said" it through its fictive voice, as it is now "speaking" these points in poetics. The poet is innocent of any offenses against love or truth and "oughte ben excusid" (PLGW, G 339). He never affirmed, and therefore he did not lie, as Boccaccio (long before Sidney) had written in his "defense of poetry," the Genealogia deorum (14-15). ${ }^{32}$

But the God of Love, we may be sure, does not read in this way. $\mathrm{He}$ is confused by shaded meanings and elliptical secret senses, such as we find in allegory, and prefers storial sequences, meanings that are obvious - that can be picked from the text like "corn." He is Chaucer's foil of the reader, not every reader certainly, but one who is uncomfortable with the sense of words that goes against the grain of narrative sequence. Such a reader is likely to underread poetry like Alceste's extended "allegory of reading" or overreact to it. The God of Love, especially, has overreacted; he needs the guidance of cool, rational response, and that is one reason Alceste appeals for the bulk of her speech to his "lordship." Reason, the traditional sign of the "ryghtwys lord" of thought, says Alceste, will not respond "lyk tyraunts of Lumbardye" (PLGW, G 353-354). The "lord" of such a reader will respond with distance and detachment to the claims of texts and will not assent to them as if they were documentary truth demanding immediate action; for the claims of fiction are "excusacyouns," "compleyntes," and "petyciouns" argued in the court of reading; they will be answered "in duewe tyme" (PLGW, G 362-364). This kind of disengagement, says Alceste finally, is the "sentence of the philosophre" (PLGW, G $\left.3_{6} 6_{5}\right)$ : it characterizes the rule of just courts. But it is also the "sentence" of the poet, his expectation that readers will appreciate with detachment the game of language, even when it plays with words like "sentence." The God of Love does not appreciate Alceste's language, because of his demand for the "pleyn text." Throwing out all the "draf" of words in order to grasp the "corn" of meaning, his reading assumes the utter self-disclosure of the speaker's intention; he hears only what he wants to hear: the poet is guilty. Alceste concedes this position, too. But although the secret senses of her alle-

${ }^{32}$ Boccaccio on Poetry, 1930, trans. Charles G. Osgood (New York: Liberal Arts Press, 1956), p. 65 . 
gory of reading are beyond her own grasp, they are nonetheless heard in the voice of the text controlling her discourse. Like her beguiling appearance before the dreamer, the pleasure of her discourse is that it lingers in the shadow of full disclosure as a text of much greater fascination in its play of simultaneously veiling and exposing intention than the dreamer's wish-by now forgotten - for the "naked text."

Yet the dreamer's fascination with Alceste, for the most part, has not characterized the general response to the "Prologue" to The Legend of Good Women. Not finding a solution to the problems of sources and meaning in her defense, readers have looked to the poet's own self-defense near the end of the poem (PLGW, G $44^{6-464)}$ but have not found it there either. As one commentator argues: "the 'Prologue' closes with the poet . . . no more certain than before." ${ }^{33}$ In a qualification of this position, another reader observes that Chaucer does give us an answer to the question of sources: he is no longer interested in courtly love poetry. Chaucer's poem is a "prologue" to the problem of "choice," and he has made his in favor of a new direction in "narrative." According to this view, the choice of "story" is Chaucer's intention in the "Prologue." ${ }^{\prime 3}$ However, the question of intent, which is itself a subject of study in the poem, is exposed as a principle that is not so comfortably assimilated to narrative. First of all, intention is something, according to the story, that an author has "in mind" and that is conveyed into a new container, a "tonne," the text of the poem. The narrative assumes this conception of intent, for instance, when the God of Love asks the poet: "Was there no good matere in thy mynde?" ( $P L G W, G$ 270). And the narrative moves ahead trying to find out just what the poet did have in mind that would motivate him to compose works as unflattering to the service of the God of Love as Troilus and the Romance of the Rose. In answer, the narrative insists on the reading of the God of Love and Alceste, that the poet had nothing good in mind at all and therefore must do "penaunce" to assuage his guilt. At long last the poet's intention is exposed, authority in narrative is reinstated, and meaning is no longer questionable.

${ }^{33}$ Payne, Key, p. 110.

${ }^{34}$ Frank, Chaucer and "The Legend," pp. 33-35. 
But from the begining of the poem other matters have continued to run counter to narrative sequence and have called into question its claim to authority in the matter of books and intention. The narrator's opening trust in fictions conflicts with belief in invisibilia; Bernard both is and is not an identifiable authority for such belief; Alceste's defense concedes the guilt of the poet and yet vindicates poetry. These matters gain their importance because story seeks authority over them yet cannot quite prevail. The poem is interested in much more than its story, and Chaucer makes this point distinct by frustrating the narrator's dream of a "naked text" of exposed intent. When the poet finally is permitted his own apologia, all he can muster is that he is not guilty. He commences by acknowledging the supernatural wonder of the queen; he knows not what she is, and then he utters in all simplicity:

"Naught have agilt, ne don to love trespas.
For-why a trewe man, withoute drede,
Hath nat to parte with a theves dede;
Ne a trewe lovere oghte me nat to blame,
Thogh that I speke a fals lovere som shame.
They oughte rathere with me for to holde,
For that I of Criseyde wrot or tolde,
Or of the Rose; what so myn auctour mente,
Algate, God wot, it was myn entente
To forthere trouthe in love and it cheryce,
And to be war fro falsnesse and fro vice
By swich ensaumple; this was my menynge." (PLGW, G 453-464)

This protest will be heard again, for example, in the "Prologue" to The Miller's Tale - "blameth nat me" (3181). But before the King and Queen of Love, the poet protests the accusations made against him on the grounds that his "intention" was merely to follow "what so myn auctour mente." Furthermore, readers should blame themselves, not the author, when they recognize unfavorable self-reflections in his fictions: honest persons, after all, are not implicated in the acts of thieves, and neither are "trewe lovers" just in blaming a poet for shaming a "fals lovere." Intention in this defense is still a mental conveyance from the writer's mind to the vessel of the book.

However, the defense itself redefines the idea of intent by relocating it from the mind of the author to the act of interpreting that is ongoing in the process of reading and writing. For as the poet is speaking of the "intent" in his "author's" mind, his words are carry- 
ing out their own "entente." The appeal to the authority of the proverbial expression about the "trewe man" and the "thief" plays out its own authority on his expression, since the lines also mean that the author, like an honest man, has no more actual part in the deeds of his characters than a witness has in the deeds of a thief. The reader ought to trust the tale, not the teller, in the determination of what a text intends. More pointedly, readers should not blame the author when a "fals lovere" is shamed, for he is not recording biographical facts. But those who do impute blame to him, as the God of Love does throughout the "Prologue," have put their own purity into question by their claim to it. So does the pretense to truth in fiction become the "assay by preve" for its own assertions. Not only has the God of Love indicted himself in his protest at court, he has also exonerated Chaucer, the poet of Richard's court, who has no "parte with a theves dede" or with anyone else he may invent. The conception of intention in these lines is no longer what the author bears "in mind," for the "poet" speaking these lines clearly does not recognize their full meaning, nor does the God of Love, who has just been roundly put in his place; rather, intention comes into being through the process of discovering how the narrator's assumptions conflict with the intentions of the text. It has a determination of its own, one that shows its significance by opposing the narrative expectation for clear and simple sense.

Nowhere is this opposition more evident than in the dreamer's opening request of Alceste in his defense, to "knowe sothly what ye be" (PLGW, G 450). The answer is given by the God of Love a few lines before the end of the poem, and it is the kind of answer he likes to give, one in which words unveil without secrets true intentions. To the observation that Alceste makes known what she is, the God of Love responds: "That is a trewe tale" (PLGW, G 495). But the narrator still does not see the "entente," until the God of Love draws the parallel between daisy, queen, and Alceste and exhorts the poet to go off and look her up "in a bok, lyth in thy cheste" (PLGW, G 498). The reference has motivated many subsequent readers who, trusting in the authority of the God of Love and the invitation of narrative to lead interpretation in the right direction, have sought to identify - though with little success to date - what book he may have had in mind. The story moves naturally toward the end of establishing such validations for knowledge. But that is also where it began. What "assay" is there to "preve" things not seen? Which "Bernard" exactly is intended? What are the sources for authority? The narrative, as the God of Love controls it, moves 
us again toward the expectation that the poet is keeping something hidden in his mind about the Alceste in the "bok" in his "cheste." But since the book we have just read tells the story of the queen who is the daisy and who is named Alceste, then perhaps we ought to listen to the authority of the play of words and look her up in the "Prologue" to The Legend of Good Women.

Like The House of Fame, the "Prologue" to The Legend of Good Women holds our interest at those moments when we are uncomfortable with the direction of the story, when the poem protests against the way it invites us to find sense principally in sequence. The "Prologue," however, has not usually been read this way, and the result has been the feeling that it is one of Chaucer's least accomplished pieces, even one of his failures. Read as a preface to the subsequent legends of good women, the story concedes the writer's ineptitude as a rather bluntly ironic gesture attempting to display his ability to entertain those at court who might have accused him of antifeminism. If considered as a treatise in poetics, the poem never gives the poet enough of a chance to defend himself and explain the conflict of books and experience: the story stalls. And as a poem in the genre of the dream vision, the "Prologue" amounts to a pastiche of earlier sources, a work without refined narrative coherence or developed characterization, despite the efforts of redaction many years after the first draft. So long as the proprieties of narrative, character, and sentence remain the primary grounds of evaluation, the reputation of the "Prologue" to The Legend of Good Women will not fare well. It will be diminished by the same expectations that have been put upon The House of Fame, in which the demand for storial sense or no sense assumes that an indeterminate beginning, middle, or end is a violation of good form. But neither poem need be bound exclusively to such demands. For the pleasure of response arises when narrative can no longer make complete and convenient sense of what we read. From such moments of invitation, only the God of Love and readers like him would turn away. He cannot appreciate the value of indeterminate form, but Chaucer obviously does; and in The Canterbury Tales, it is before us again in a variety of ways, to which I will turn next. 